\title{
AN ESSAY CONCERNING THE FOUNDATIONAL MYTH OF ETHNOPHILOSOPHY
}

DOI: http://dx.doi.org/10.4314/ft.v5i1.7

\author{
Aribiah David ATTOE, csp \\ Department of Philosophy, University of Calabar
}

\begin{abstract}
Ethnophilosophy, although glorified by some African philosophers, remains a problem in our undertakings in African philosophy. In its infancy, the problem revolved around the call for a total decolonization of African thought and philosophy, which eventually led to the proliferation of a vast array of mostly descriptive literature about the cultural views and practices of the African, sold to us as not only philosophy but genuine African philosophy. In more recent times, due to the growing development of African philosophy, this drive towards description is gradually waning and from its dying flames, a new and more subtle problem has arisen. This problem lays in the call by most African philosophers, to make philosophy done in Africa to be more African in nature, the methodology and/or logic of African philosophy becomes a narrow discourse which is based on the dogma of descriptive story telling of ethnophilosophy. This is the problem which this essay seeks to address. Thus I shall in this essay, expose the myth of ethnophilosophy and thereafter suggest that African philosophy builds its foundation on criticality rather than ethnophilosophy. As an addendum to this, it is also suggested here that the narrow nature of the false descriptive methodology of mainstream African philosophy (which is based on the more subtle implications of ethnophilosophy) be at the very least, de-emphasised. I shall employ conversationalism as the method of my inquiry.
\end{abstract}

Keywords: Ethnophilosophy, myth, African philosophy, conversationalism, conversational school

\section{Introduction}

This essay is the first in a series of short essays (that I hope to publish in this Journal), that will attempt to address certain myths intrinsic in our understanding of certain philosophical concepts and ideas as well as stir up conversations concerning the issues being addressed and it is apt that I begin with one that is dear to our studies in African philosophy - Ethnophilosophy.

As a direct consequence of this myth, African philosophy is constantly being presented as what-it is not. Most scholars within the ambit of African philosophy often tend to forcefully impose the concept of philosophical on certain stories, ¿otraditions, norms, folklore etc whereas some of these ideas in themselves, are anything but philosophical (HOUNTONDJI 2004, 529-530). 
Beyond the consequence of making African philosophy a project of descriptive story-telling, the myth that ethnophilosophy serves as a veritable foundation to authentic African philosophy as propagated by the likes of Ada Agada (2015) is worrisome. In the over-zealousness of most African philosophers to portray the relevance of African philosophy, focus has shifted from philosophising about ideas, to a descriptive narrative of what ideas to philosophise about in order to achieve authentic African philosophy, ultimately mistaking the latter as the former. What is most worrying about this sort of mindset is that in the bid to - as true Africans - decolonise philosophy as it is done in Africa and/or Africanise the philosophy curriculum in Africa, we lose sight of what philosophy should be. Philosophy reverses its role as a tool for creating and criticising worldviews and ultimately becomes a tool for intellectual politicking. Such an Africanised curriculum or mode of thinking, in a most definitive manner, narrows the imaginative character and intellectual horizon of the African philosopher.

A host of philosophers have had to face severe diatribes from Afrocentrists such as (ONYEWUENYI 1993; OLELA 1984; MOMOH 2000, etc.); for their position that philosophy should not be watered down in a desperation to establish the existence of African philosophy. These philosophers like (HOUNTONDJI 1996; ORUKA 1975; WIREDU 1980, BODUNRIN 1984; WRIGHT 1984; MAURIER 1984, etc.,) who are clear-minded on how philosophy should proceed in the African place have been accused of Eurocentrism and even of logocentricism (OUTLAW 2003). These issues are not the concern of my paper so I shall let them be. My concern has to do with the resurgence of ethnophilosophy in our time specifically as it is being marketed as the very foundation of African philosophy. It is my conviction that any philosophy that is worth its name must stand on a firm foundation. Ethnophilosophy is no such foundation.

This is the problem which this essay seeks to expose and will attempt to address. In order to achieve this, I shall begin by exposing what I call 'the myth of ethnophilosophy'. In addressing this myth, this essay hopes to stir up conversations that would invariably redirect the study and course of African philosophy from ethnophilosophy to philosophy proper.

\section{The Myth}

Philosophy must have an object of study, what it is critical about, what it doubts, the questions it seeks to address, etc., and this object of study is reality. Through our rationalisations and experiences, we encounter reality, plough through the surface of our understanding of reality, in order to expose certain problems and inconsistencies and then attempt to address these inconsistencies, more often than not, raising more opproblems by doing so. Philosophy itself is usually seen as a second order discipline $\approx$ and ultimately universal in its logic. This logic, as most scholars of African philosophy are quick to point out, was usually based on what I shall call the 
"Western paradigm" of philosophy. Armed with its mainly two-valued logic, laws of thought and other such alleged shenanigans, philosophers of the Western paradigm were quick to judge and/or dismiss as invalid, illogical or just plain nonsensical, the prevailing thoughts of other cultures (in this case African thought) or paradigms that did not fully participate in their mode of doing philosophy. This Western paradigm failed to take into cognisance the fact that reality differed, apparently depending on one's geographical and/or cultural context, and as such, it only followed that addressing this context-based realities, one needed to have a corresponding philosophy, tailored towards each specific reality. As a colonising power after the advent of slavery, it is no surprise that within the African context, the Western Paradigm is often seen as a colonising mentality which seeks to consciously but subtly suppress the indigenous thought patterns of the African. Thus the philosopher from Africa becomes at best, an intellectual recluse, ashamed of his "bush" worldview or worse still, an unoriginal thinker, unable to think on his own and at the same time applying an alien Western paradigm on indigenous problems, when the two are not of the same logical order - disaster.

This chain of implications advanced the need for indigenous philosophies and in this context, African philosophy - to find a solid ground in order to have a solid footing in an ocean of Western thought. Ethnophilosophy thus served as one of such seemingly firm foundations on which indigenous philosophies, including African philosophy can stand. The term Ethnophilosophy, Ozumba states, was a term used by Paulin Hountondji to refer to the "works of those anthropologists, sociologists, ethnographers and philosophers who present the collective world-view of African people, their myths and folklores and folk-wisdom as philosophy" (OZUMBA 2009, 9). Ethnophilosophy as I see it, involves a mutual exclusivity and isolation of varying philosophies based on geographical and cultural divide. It is based on the assumption that each society or culture possesses its own unique philosophy which may not be applicable to other cultures. Asouzu describes Ethnophilosophy in no uncertain terms as "that variant of ethnocentric inspired method of inquiry that is easily identifiable. It is that variant of philosophical methodology which considers collecting, describing and informing over the general worldview of a people the target of philosophical investigation. It thereby underestimates the role which personal critical reflection plays in inquiry" (ASOUZU 2007, 37). The more profound thesis of ethnophilosophy is that philosophy is a product of culture and as such, culture and/or geographical bearings remain the supreme determinant factor of one's philosophy - differing cultures implying different strands of independent philosophies. Affixed to this view is the Nenchant to see philosophy as an "us" versus "the others" enterprise, with each cultural variant of philosophy (especially the African brand), enjoined to defend its "territory" with much verve, in order to enjoy relevance and legitimacy.

$\underset{\sigma}{\infty}$ Armed with this propaedeutic, it is not difficult to see why a self-pronounced

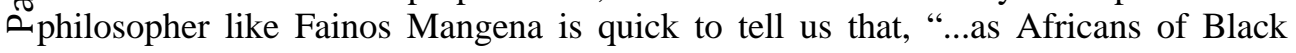
extraction, we were doing a disservice to our very own philosophy called Ethno- 
philosophy in [our] ridicule [of it]" he further concludes categorically that ethnophilosophy "is the only philosophy an African of black extraction can be proud of as it is rooted in African tradition and cultures" (MANGENA 2014, 96). Context, perspectivism, relativism and/or subjectivism in its most potent form thus become the building blocks of ethnophilosophy. Pushing this argument further, Ada Agada moves in the same direction, albeit taking a different path. He opines that the narrative of ethnophilosophy should however adopt Africa as its constituency rather than individual tribes (AGADA 2015, 42). For him, ethnophilosophy in the first and second decades of the $21^{\text {st }}$ century deserves the myriad of criticisms it is getting and also suggests a redirection of those criticisms to those "inferior ethnophilosophers" who are more akin to addressing their tribesmen and inadvertently ensuring that "African philosophy in the $21^{\text {st }}$ century remains primitive and polemic instead of constructive and critical" (AGADA 2015, 42). While it may be easy to accept Agada's position, it only serves to widen the ethnocentric commitments of that brand of African philosophy from the tribe to the continent and the problems associated with ethnophilosophy proper still remains. The traditional thought systems (folktales, proverbs etc) of ancient Africans which Agada considers the fodder for contemporary African philosophy which are mainly descriptive and hardly criticised, can scarcely be considered as the only proper "fodder" or foundation befitting of African philosophy. In fact, Agada declares that ethnophilosophy is the proper foundation of African philosophy $(2015,35)$.

Were we to take ethnophilosophy and the view that philosophy is a product of culture to its logical conclusion; the following immediately becomes undeniable;

1. Philosophy is a jamboree of different cultural views. Each of which must be valid and sound, and none of which can be wrong, via context.

2. Philosophy is dead and reduced to mere sociological dogmatism as the sacrosanct nature of "cultural context" becomes it new logic.

It may indeed be possible that the above truly is the case, however, let us proceed to analyse the finer details of the issue at hand before such conclusions are made.

\section{Addressing the Myth}

Let us be meta-philosophical for a moment and examine philosophy itself. Philosophy is a product of critical reflection; from critical thoughts about the cosmos, to critical reflections about humans and their interpersonal experiences etc. Beyond mere wondering, philosophy seeks to critically examine the fundamental nature of

Mbeing (reality), through questions, counter-questions, responses and counterresponses. What is a recurrent theme in the study of philosophy is the search for truth as well as demarcating truth from falsehood. Although getting at truth is difficult, okknowledge of what is false is a much easier affair. Philosophy thus possesses the

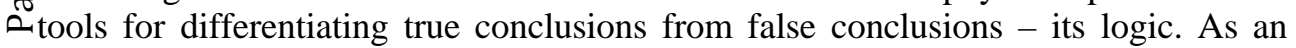
object of study of philosophy, it would most likely be absurd for one to claim that 
philosophy is borne out of culture - that is a myth. If anything, philosophy transcends culture and should be a constant critic of culture - which in all honestly should be seen as a bandwagon appeal to authority, which has over time solidified as a way of perceiving and manipulating reality. This view does not however discredit the fact that our unique landscapes and geographical enclave poses unique and somewhat differing realities and problems. However, what this fact only implies is that the objects of study of philosophy may differ in certain respects and as such although certain areas of confluence regarding the subject matter of their philosophies may exist in some respects, it may also differ based on the differing realities their philosophers may encounter. What is worthy of note in all this is the fact that the methodology of philosophy i.e. its tools for identifying falsehood is generally left untouched by both our cultures and differing realities - it is not a product of these factors. To claim otherwise, is to assert, for instance, that because the topography (land, air, water, urban, jungle, etc.,) influences the style of warfare, such topography therefore defines the idea of war itself - which naturally, is to subdue the enemy. It advertently creates a jamboree of philosophies and philosophical claims whose truth worthiness is based on the subjectivity of cultures, inclusive in its acceptance of all claims valid and nonsensical, and exclusive of all criticism on the basis of context. An unscrupulous African philosopher may thus present tales and folklore about thunder gods, chickens and creation, new yam festivals, etc., and pass it off as truth and/or philosophy by rejecting all claims of ludicrousness on the basis of the fact that his critics are not Yoruba (or African). What philosophy thus becomes is an enterprise, not in criticality but an untouchable descriptive narrative of an object of study, placed on the high altar of differing contexts - it becomes the travesty we now know as ethnophilosophy - forgetting that self-criticism as Kolawole rightly points out is the starting point of the philosophical programme because through criticisms, fundamental questions about a subject matter, continues to be raised (KOLAWOLE 1999, 60). For those of us in the Conversational School of Philosophy, we talk about conversations and the sustenance of this critical conversations is paramount to the growth of a philosophy programme (CHIMAKONAM 2015, 465).

Although the object of study of philosophy may differ across the various geographical divides that exist in the world, it does not however imply that philosophy itself or at least its methodology is different. No matter the reality we are trying to understand, the tools for demarcating truth from untruth, remains universal. These tools I identify as logical validity/soundness and pragmatic viability. That for instance, for most Africans, certain trees or certain inanimate objects may possess spiritual powers is only a premise and a matter for debate, not a philosophy or a total falsehood, which is based on the context of being African or non-African respectively. In other words this essay suggests that unlike the mythical tales of ethnophilosophy, philosophy qua philosophy remains a universal discipline and, I Dodaresay, not a product of one's culture or geographical divide and should be seen as

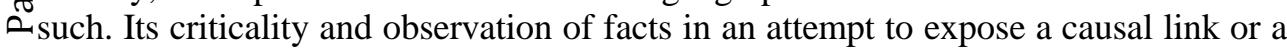


chain of logical implications if any, as well as its drive to differentiate a sequitur from a non sequitur is universal and beyond the myth of ethnophilosophy.

Ethnophilosophy, I think, is a politically driven enterprise, an Afrocentrist campaign that is not in keeping with the tradition of true philosophy. It is driven by the need to safeguard one's identity as a philosopher from a certain culture, in a world dominated by the Western paradigm. With most African scholars on the offensive, the lines between ethnophilosophy proper and what I term philosophical racism are quite blurred and sometimes even non-existent. Philosophical racism is that urge to reject, suspect and disregard as irrelevant, a philosophical argument based on the cultural affiliations of the scholar involved. The tendency of most African philosophers to reject a notion based on continental affiliations rather than critical conversations only goes to buttress this point. The inglorious declarations of the irrationality of Africans by most Western scholars such as Hegel, Levy-Bruhl, Hume, Herbert Spencer, Max Muller, etc., as well as the drive to, as Uduma Oji puts it, "rationalise Africans out of humanity" by most Eurocentric scholars (UDUMA 2014, 127), had activated most African scholars to react, by basically showing that Africans too can do philosophy and in so doing, allowing all sorts of beliefs and ideologies to pass as African Philosophy (OYESHILE 2008, 59). However, when criticised some of these African Philosophers have created for themselves a mythical enclave of anti-philosophy with which to hide, deflecting all arrows of alleged westbased criticism on the basis of citizenship and context.

In line with the will to ethnophilosophy, there have been certain calls to indigenise or Africanise the curriculum of the philosophy taught in African tertiary institutions. ${ }^{1}$ Although it is not a bad thing to make African students aware of their peculiar problems, the concern here is that by placing more emphasis on the differences in philosophical problems between the Westerner and the African, the student becomes a narrator, losing the ability to properly philosophise. Such a curriculum would rather teach students what to philosophise about exactly (which is context driven), rather than how to philosophise (which is universal). Our mode of studying and teaching philosophy should be redirected back to the latter. This is therefore what is necessary for true philosophical growth to be achieved in African philosophy.

I am aware that a group of African philosophers - what one may describe as the Johannesburg Think Tank - from different universities across three continents gathered in September 2015 in the city of Johannesburg to discuss the possibility of Africanising the philosophy curriculum in African universities. The output of that meeting is to be ๘published as a special issue of the South African Journal of Philosophy later in 2016. Some of us are curiously awaiting this publication. 


\section{Conclusion}

I have in this essay, sought to expose us to the conceptual deceptions of ethnophilosophy as well as the inconsistencies inherent in our intended or (sometimes) unintended use of ethnophilosophy as a template for how we do African philosophy. The exclusivist nature of ethnophilosophy ironically engenders philosophical underdevelopment and unoriginality in Africa. Thus whilst the ethnophilosopher fantasises about the philosophical nature of proverbs and folklore or the viability of ancient communitarianism in the modern epoch - invariably stuck in primeval traditionalism; giant strides are being made and new innovative ideas in all aspects of philosophy are constantly being churned out by others elsewhere. It is hoped, as earlier said, that in the spirit of true philosophy, this essay stirs up conversation concerning the direction of African philosophy, its true nature, the proper methodology for doing African philosophy and finally the question - does African Philosophy really need to be made African?

\section{Relevant Literature}

1. AGADA, Ada. [Existence and Consolation: Reinventing Ontology, Gnosis and Values in African Philosophy]. 2015. $3^{\text {rd }}$ Logic Option Publishing: Calabar. Paperback

2. ASOUZU, Innocent. [Ibuaru - The Heavy Burden of Philosophy Beyond African Philosophy], 2007. LIT VERLAG GmbH \& Co. KG Wien: Zurich. Paperback

3. BODUNRIN, Peter."The Question of African Philosophy", [African Philosophy: An Introduction, 3rd ed. Wright, Richard, ed], pp. 1-24, 1984. University Press of America: Lanham, Md. Paperback.

4. CHIMAKONAM, Jonathan. O. "Transforming the African philosophical place through Conversations: An inquiry into the Global Expansion of Thought (GET)." [South African Journal of Philosophy], Vol. 34, No. 4, Pp. 462-479, 2015. Paperback.

5. HOUNTONDJ, Paulin. "Knowledge as a Development Issue."[A Companion to African Philosophy, Kwasi Wiredu, Ed.], Pp. 529-537, 2004. Blackwell Publishing: Oxford. Paperback. 
Filosofia Theoretica: Journal of African Philosophy, Culture and Religions

6. ___ [African Philosophy: Myth and Reality, Second Revised ed.], 1996. Indiana University Press, Bloomington. Paperback.

7. KOLAWOLE, Owolabi. "Orientations in African Philosophy: A Critical Survey." [Indian Philosophical Quarterly], Vol. 26, No. 1, Pp. 59-70, 1999. Web.

8. MANGENA, Fainos. "'In Defense of Ethno-Philosophy: A Brief Response to Kanu's Eclectism."' [Filosofia Theoretica: Journal of African Philosophy, Culture and Religions], Vol. 3, No. 1, Pp. 96- 107, 2014. Paperback.

9. MAURIER, Henri. "Do We have an African Philosophy?", [African Philosophy: An Introduction, 3rd ed. Wright, Richard, ed], pp. 25-40, 1984. University Press of America: Lanham, Md. Paperback.

10. MOMOH, Campbel S. "Nature, Issues and Substance of African Philosophy", [The Substance of African Philosophy, $2^{\text {nd }}$ edn, C. S. Momoh ed.], pp. 1-22, 2000. APP Publications: Auchi. Paperback.

11. ODERA, Oruka. "The Fundamental Principles in the Question of African Philosophy", [Second Order],Vol.4, No. 1. 1975. Pp. 44-55, Paperback.

12. OLELA, Henry. "The African Foundations of Greek Philosophy", [African Philosophy: An Introduction, 3rd ed. Wright, Richard, ed], pp. 77-92, 1984. University Press of America: Lanham, Md. Paperback.

13. ONYEWUENYI, Innocent. [African Origin of Greek Philosophy: An Exercise in Afrocentrism], 1993. SNAAP Press: Enugu. Paperback.

14. OUTLAW, Lucius. "African 'Philosophy: Deconstructive and Reconstructive Challenges", [The African Philosophy Reader, edited by Peter .H.Coetzee and A.P.J.Roux], pp. 162-191, 2003. Routledge: London. Paperback.

OYESHILE, Olatunji. "On Defining African Philosophy: History, Challenges and Perspectives." [Humanity \& Social Sciences Journal], Vol. 3 No. 1, Pp. 57-64, 2008. Web.

OZUMBA, Godfrey. "An Examination of Bodunrin's "The Question of African Philosophy." [From Footmarks to Landmarks on African Philosophy, 
Andrew Uduigwomen Ed.], Pp. 8-13, 2009. O.O.P. Limited: Lagos. Paperback.

17. UDUMA, Oji Uduma. "The Question of the "African" in African Philosophy: In Search of a Criterion for the Africanness of a Philosophy."[Filosofia Theoretica: Journal of African Philosophy, Culture and Religions], Vol. 3 No. 1, Pp. 127- 146, 2014. Paperback

18. WIREDU, Kwasi. [Philosophy and an African Culture], 1980. Cambridge University Press: Cambridge. Paperback.

19. WRIGHT, Richard A. "Investigating African Philosophy", [African Philosophy: An Introduction, 3rd ed. Wright, Richard, ed], pp. 41-55, 1984. University Press of America: Lanham, Md. Paperback. 